\title{
The Alloying Behaviour of Gold
}

\author{
Professor G. V. Raynor
}

Department of Physical Metallurgy and Science of Materials, University of Birmingham, England

\section{PART II COMPOUND FORMATION}

In the first part of this review the factors affecting the formation of solid solutions in gold alloys were discussed. We now turn to the considerations governing the formation and stability of compounds of gold with other metals.

\section{The 3/2 Electron Compounds}

In many alloys of copper and silver with B subgroup elements the primary solid solution is in equilibrium over a specific temperature range with a phase which has a range of homogeneity including the composition equivalent to an $\mathrm{e} / \mathrm{a}$ value of 1.5 . Thus body-centred cubic $\beta$ phases occur at compositions close to $\mathrm{CuZn}, \mathrm{Cu}_{3} \mathrm{Al}, \mathrm{Ag}_{3} \mathrm{Al}$ and $\mathrm{Cu}_{5} \mathrm{Sn}$, while ordered forms $\beta^{1}$ are found at compositions $\mathrm{AgMg}$ and (at low temperatures) CuZn. Complex cubic $(\mu)$ structures of the $\beta-\mathrm{Mn}$ type also occur $\left(\mathrm{Cu}_{5} \mathrm{Si}, \mathrm{Ag}_{3} \mathrm{Al}\right)$, while in some cases the structure occurring is the close-packed hexagonal $\zeta$-phase $\left(\mathrm{Cu}_{3} \mathrm{Ga}, \mathrm{Cu}_{5} \mathrm{Ge}\right.$, $\mathrm{Ag}_{5} \mathrm{Sn}$ ). Gold alloys conform closely with those of copper and silver. Among the gold alloys (see also Table III) the following systems contain $3 / 2$ electron compounds:

$\beta$ : $\mathrm{Au}-\mathrm{Al}$ at higher temperatures $\left(>300^{\circ} \mathrm{C}\right.$ to $\left.400^{\circ} \mathrm{C}\right)$; $\mathrm{Au}-\mathrm{Ga}$

$\beta^{1}: \mathrm{Au}-\mathrm{Cd} ; \mathrm{Au}-\mathrm{Mg} ; \mathrm{Au}-\mathrm{Zn}$

$\mu: \mathrm{Au}-\mathrm{Al}$ at lower temperatures $\left(<300^{\circ}\right.$ to $\left.400^{\circ} \mathrm{C}\right)$

$\zeta: \mathrm{Au}-\mathrm{In} ; \mathrm{Au}-\mathrm{Sn}$

Factors affecting the formation and stability of $3 / 2$ electron compounds were discussed by HumeRothery, Reynolds and Raynor (11); in brief, their conclusions were:

(a) Increasing solute valency favours the $\zeta$ or $\mu$ structures at the expense of the $\beta$ or $\beta^{1}$ phases.

(b) Increasing temperature favours the $\beta$ structures at the expense of $\beta^{1}$, $\zeta$ or $\mu$ structures.

(c) Increasing size factor favours the $\beta$ structures at the expense of the $\zeta$ or $\mu$ structures.

(d) Increasing size factor moves the composition of the $3 / 2$ electron compounds towards lower e/a values and also narrows the range of composition of the phases in terms of electron concentration.

(e) The tendency to form $\beta^{1}$ structures in copper, silver and gold alloys is in the order gold $>$ silver $>$ copper.

Gold alloys conform fully with these tendencies. As an example of $(a)$, the structure of the Au-Cd 3/2 electron compound is ordered body-centred cubic while that for the corresponding $\mathrm{Au}-\mathrm{Sn}$ phase is close-packed hexagonal. Similarly the Au-In system contains a $\zeta$ phase and the Au-Al 3/2 electron compound has the $\mu$ structure at low temperatures. In relation to tendency $(b)$, the Au-Ga system contains a $\beta$ phase at the higher temperatures. The Au-Al system contains a $\beta$ phase at the higher temperatures and a $\mu$ phase, of effectively the same composition, at lower temperatures; no system shows the reverse behaviour. For gold as solvent, tendency $(c)$ is somewhat obscured by the formation of ordered $\beta^{1}$ phases, the stability of which may over-ride the effect of a small size factor. Thus, in addition to $\beta^{1}$ phases in the systems $\mathrm{Au}-\mathrm{Zn}$ (size factor -7.61) and $\mathrm{Au}-\mathrm{Mg}$ (size factor +10.84) a $\beta^{1}$ structure is found in the Au-Cd system (size factor +3.30). These observations conform to tendency (e) which emphasises the chief difference between $3 / 2$ electron compound formation in gold alloys and in alloys of copper and silver. The normal electrode potentials of the noble metals are as follows:

$$
\mathrm{Cu} \rightarrow \mathrm{Cu}^{+},-0.47 \mathrm{~V} ; \underset{-1.50 \mathrm{Ag}}{\rightarrow} \mathrm{Ag}^{+},-0.80 \mathrm{~V} ; \mathrm{Au} \rightarrow \mathrm{Au}^{+},
$$

Gold is therefore the most electronegative, and when

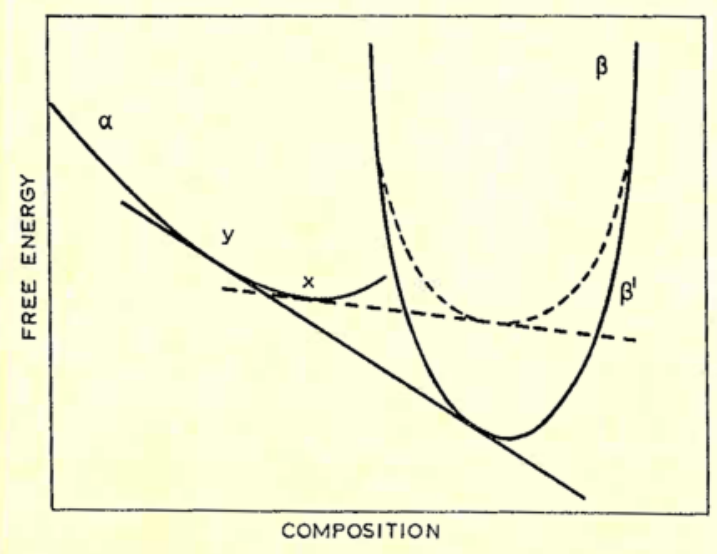

Fig. 9 Hypothetical free energy diagram for equilibrium between solvent-rich solid solution and a $3 / 2$ electron compound at a given temperature. Point $x$ defines the solid solubility limit for equilibrium with the less stable $\beta$ phase, while point $y$ defines the lower solubility for equilibrium with the more stable $\beta^{1}$ phase of lower free energy 
alloyed with an electropositive element (such as magnesium) order is encouraged by the tendency to form unlike nearest neighbour pairs of atoms. For this reason, $\beta^{1}$ phases occur in the systems $\mathrm{Au}-\mathrm{Zn}$, $\mathrm{Au}-\mathrm{Cd}$ and $\mathrm{Au}-\mathrm{Mg}$, whereas among silver alloys only the $\mathrm{Ag}-\mathrm{Mg}$ system exhibits a $\beta^{1}$ phase. The congruent melting point of $\beta^{\mathbf{1}}{ }_{\mathrm{Au}-\mathrm{Mg}}$ considerably exceeds that of $\beta^{1}{ }_{\mathrm{Ag}-\mathrm{Mg}}$ in conformity with the more electronegative character of gold. The marked stabilities of these two phases are responsible for the depression of primary solid solubilities of magnesium in gold and silver below that characteristic of the $B$ sub-group elements. This may be understood in terms of Figure 9 which shows how the points of contact of the common tangent to the free energy curves for the solid solution and the electron compound, which define the compositions in equilibrium at a given temperature, are affected by the relative free energies of the phases. Further reference is made to this principle in connection with the $\gamma$-brass phases.

\section{The 21/13 Electron Compounds}

Electron compounds with the structure of $\gamma$-brass, or slightly deformed variants of this, occur in many noble metal alloy systems at compositions approximating to an $\mathrm{e} / \mathrm{a}$ value of $21 / 13$. The factors affecting the formation of this phase have been discussed by Hume-Rothery, Betterton and Reynolds (12). The structure is complex cubic (52 atoms per unit cell) and corresponds with an electronic energy band such that all available levels would be filled by 90 electrons, giving an e/a value of 1.73. Application of elementary electron theory indicates that $\gamma$-brass phases should become unstable with regard to alternatives at $\mathrm{e} / \mathrm{a}$ $=1.54$, whereas the empirical ratio $21 / 13$ corresponds with $\mathrm{e} / \mathrm{a}=1.615$. It is therefore proposed that the density of electronic states curve has the form of Figure 10 where the second steep fall is the important feature. In some cases the range of homogeneity is very wide, with the solute-rich boundary occurring at e/a values of 1.82-1.84. Where this occurs, the $\gamma$ structure with a full complement of 52 atoms per unit cell is maintained until the e/a value reaches 1.7 (87-88 electrons per unit cell).

Above this limit comparison of lattice spacing and density measurements shows that atoms are omitted from the structure to maintain a constant number (87-88) of electrons per unit cell. This is illustrated for $\mathrm{Cu}$-Al alloys in Figure 11. A normal $\gamma$-brass phase (all atomic sites occupied) appears to be prohibited above a constant number of 87-88 electrons per cell $(1.68-1.7 \mathrm{e} / \mathrm{a})$; at higher compositions a "constitutional defect" structure is formed. Among gold alloys $\gamma$-brass structures, or slightly distorted variants, occur in the systems

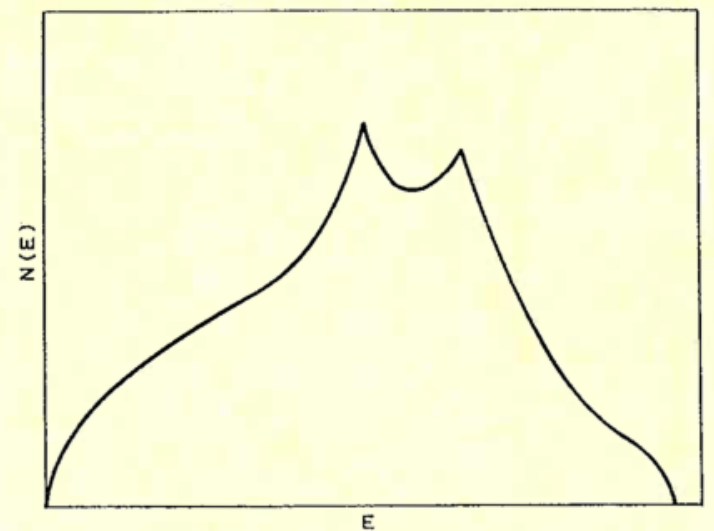

Fig. 10 Proposed form of N(E)/E curve for the $\gamma$-brass structure

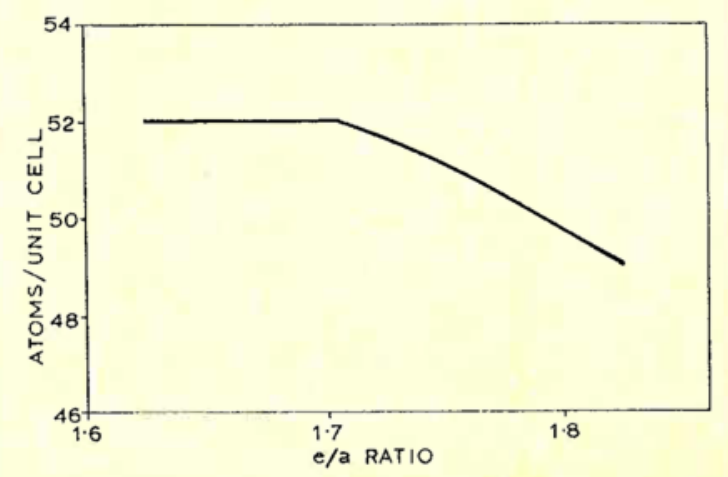

Fig. 11 Variation with composition of the number of atoms per unit cell in the $\mathrm{Cu}-\mathrm{Al} \gamma$-brass phase

$\mathrm{Au}-\mathrm{Zn}, \mathrm{Au}-\mathrm{Ga}, \mathrm{Au}-\mathrm{Al}, \mathrm{Au}-\mathrm{In}$ and $\mathrm{Au}-\mathrm{Cd}$. Only in $\gamma_{A u-Z n}$ does e/a exceed 1.7 ; the homogeneity range is very wide and must involve a defect structure, since if all lattice points were occupied the solute-rich boundary would extend beyond the point corresponding to a filled conduction band, which is improbable. Maximum stability of $\gamma$-phases appears to occur for size factors which are neither too favourable nor too unfavourable. This probably accounts for the existence of a Au-Al $\gamma$-phase and the absence of a corresponding $\mathrm{Ag}-\mathrm{Al}$ phase. In the latter case solution of silver in aluminium causes negligible lattice distortion, whereas that caused by aluminium in gold is appreciable.

Factors of an electrochemical nature, referred to for $3 / 2$ electron compounds, operate for $\gamma$-phases also. An increasing degree of electrochemical interaction displaces the homogeneity range to higher e/a values. This may be understood in terms of the free energy principles previously mentioned; just as a very stable electron compound displaces the point of contact with the solid solution free energy curve to lower e/a values (Figure 9) it will displace the point of contact with the $\gamma$ free energy curve to higher e/a values. 
This may explain the absence of $\gamma$-brass phase in the systems $\mathrm{Ag}-\mathrm{Mg}$ and $\mathrm{Au}-\mathrm{Mg}$, where electrochemical interactions are strong; the noble metal-rich boundary of the hypothetically possible $\gamma$ phase may be displaced so far from the characteristic e/a value that the phase cannot be formed.

\section{The 7/4 Electron Compounds}

In copper and silver alloys with B sub-group solutes a close-packed hexagonal phase frequently occurs at an e/a value of $7 / 4$. Typical examples are based on the compositions $\mathrm{CuZn}_{3}, \mathrm{Cu}_{3} \mathrm{Sn}$ and $\mathrm{Ag}_{5} \mathrm{Al}_{3}$. In gold alloys the phases $\mathrm{AuZn}_{3}, \mathrm{AuCd}_{3}$, $\mathrm{Au}_{3} \mathrm{Sn}$ and $\mathrm{Au}_{5} \mathrm{Al}_{3}$, all with the close-packed hexagonal structure, have been reported, and with regard to the formation of these electron compounds, gold conforms to the general theory.

\section{Other Intermediate Phases}

Many intermediate phases which are not electron compounds occur in gold alloy systems. Those which show analogies with commonly observed phases in other systems are collected in Table V. The classes of structure best represented are the $\mathrm{CsCl}$ and $\mathrm{MoSi}_{2}$ structures, mainly owing to the association of the rare earth metals with gold in these structures. Denoting the $\mathrm{MoSi}_{2}$ structure as $\mathrm{AB}_{2}$, the same elements may act as both the $\mathrm{A}$ and the $\mathrm{B}$ component. Also, where one of the metals is from group $4 \mathrm{~A}$ the axial ratios for the phases differ widely. Thus the axial ratios of $\mathrm{ZrAu}_{2}$ and $\mathrm{HfAu}_{2}$ are respectively 2.464 and 2.456; corresponding values for $\mathrm{AuZr}_{2}$ and $\mathrm{AuHf}_{2}$ are 3.536 and 3.572. For $\mathrm{MnAu}_{2}$ and $\mathrm{AuMn} \mathrm{n}_{2}$ the axial ratios are comparable and similar to those of $\mathrm{ZrAu}_{2}$ and $\mathrm{HfAu}_{2}$. As discussed elsewhere (13) a low axial ratio corresponds to a co-ordination number of 10 for a given atom and is adopted when the B atom is gold, silver, copper or a B sub-group metal. A high axial ratio corresponds with a co-ordination number of 8 and is found when the B component is an early transition metal in which $\mathrm{d}$ electrons are strongly involved in the formation of hybridised bonds so directed as to stabilise the body-centred cubic structure of co-ordination number 8 . The axial ratios adopted in the $\mathrm{MoSi}_{2}\left(\mathrm{AB}_{2}\right)$ type of phase thus appear to be the result of a tendency for early transition metals and noble metals to carry over into these compounds their different preferred bonding mechanisms when present as the predominating B component.

The phases $\mathrm{AuAl}_{2}, \mathrm{AuGa}_{2}$ and $\mathrm{AuIn}_{2}$ which crystallise in a structure similar to that of fluorspar $\left(\mathrm{CaF}_{2}\right)$ are also interesting. In other alloys many such phases are known and some (e.g. $\mathrm{Mg}_{2} \mathrm{X}$ where $\mathrm{X}=\mathrm{Si}, \mathrm{Ge}, \mathrm{Sn}$ or $\mathrm{Pb}$ ) are mainly the result of electrochemical interactions, though other factors may be involved (14). In general such phases correspond to an $e / a$ value of $8 / 3$, which could only be achieved in the phases under discussion were gold to act as a divalent component. Reference to this possibility was made earlier when discussing solid solution formation. Comment on most individual phases is unnecessary, but attention should be drawn to the small number of phases in gold alloy systems that fall into the large class of Laves phases typified by $\mathrm{MgCu}_{2}$ $\left(\mathrm{AB}_{2}\right)$, which owe their stability mainly to spatial geometry which ensures efficient space filling for an atomic radius ratio $R_{A} / R_{B} \simeq 1.2$. The atoms of few elements are either large enough to form the $A$ component or small enough to form the B component when alloyed with gold. It should also be mentioned that in gold alloy systems only one example of the important $\sigma$ phase structure is formed $\left(\mathrm{Ta}_{2} \mathrm{Au}\right)$. This structure usually involves a transition metal of group $7 \mathrm{~A}$ or 8 (as B component) in association with a transition metal of group $5 \mathrm{~A}$ or $6 \mathrm{~A}$ (as $\mathrm{A}$ component) and corresponds with a relatively narrow band of electron: atom ratios. $\mathrm{Ta}_{2} \mathrm{Au}$ is unusual in that a non-transition metal is involved; as in other cases, however, it still involves the association of a body-centred cubic metal and one with a closepacked structure. ${ }^{\star}$

Intermediate phases of unknown structure are collected in Table VI. Tables V and VI together show that the formation by gold of intermediate phases which do not have the character of simple electron compounds is predominantly with A subgroup metals. In this review some 66 solute elements have been considered, of which 37 are A sub-group elements and 29 are from B sub-groups and group 8. The number of intermediate phases in Tables $\mathrm{V}$ and VI involving A sub-group components is 139 , while only 21 involve B sub-group components.

The systems formed by gold and the transition metals of group 8 have been referred to earlier and reference was made to complete solid solution formation between gold and nickel, palladium or platinum at the appropriate temperatures. It is interesting to note that only one "intermediate" phase involving gold and these metals has been suggested $\left(\mathrm{PtAu}_{3}\right)(15)$. This is almost certainly a simple ordered structure and may be transitional in nature (16). We may also note that 52 out of 107 of the phases formed with A sub-group metals (excluding rare-earth metals and actinides) involve a component from group $2 \mathrm{~A}$ or $4 \mathrm{~A}$. The reason for this is not clear.

*Calculating on the basis of the number of electrons outside the inert gas core (the group number), the $\sigma$ phase is formed over a range of values of mean group number from 5.6 to 7.6 . Taking tantalum as of group number 5 and gold as 11 , the mean group number for $\mathrm{Ta}_{2} \mathrm{Au}$ is 7 and thus conforms. 


\begin{tabular}{|c|c|c|c|c|c|}
\hline \multicolumn{6}{|c|}{$\begin{array}{c}\text { Table V } \\
\text { Intermediate Phases other than Electron Compounds-Known Structures }\end{array}$} \\
\hline $\begin{array}{l}\text { Structure } \\
\text { Type }\end{array}$ & $\begin{array}{c}\text { Group of } \\
\text { Partner }\end{array}$ & Phase & $\begin{array}{l}\text { Structure } \\
\text { Type }\end{array}$ & $\begin{array}{l}\text { Group of } \\
\text { Partner }\end{array}$ & Phase \\
\hline \multirow[t]{3}{*}{$\mathrm{CsCl}$} & \multirow[t]{3}{*}{$\begin{array}{l}1 \mathrm{~A} \\
3 \mathrm{~A} \\
7 \mathrm{~A}\end{array}$} & \multirow{2}{*}{$\begin{array}{l}\text { AuRb } \\
\text { AuCs } \\
\text { AuSc } \\
\text { AuY } \\
\text { AuLa } \\
\text { AuMn* } \\
\\
\text { AuCe } \\
\text { AuPr } \\
\text { AuNd } \\
\text { AuPm } \\
\text { AuSm }\end{array}$} & $\mathrm{CuAl}_{2}$ & $\begin{array}{l}1 \mathrm{~A} \\
4 \mathrm{~A} \\
4 \mathrm{~B}\end{array}$ & $\begin{array}{l}\mathrm{AuNa}_{2} \\
\mathrm{AuTh}_{2} \ddagger \\
\mathrm{AuPb}_{2} \ddagger\end{array}$ \\
\hline & & & $\mathrm{TiCu}_{3}$ & $\begin{array}{l}3 \mathrm{~A} \\
4 \mathrm{~A}\end{array}$ & $\begin{array}{l}\operatorname{InAu}_{3}(\varepsilon) \\
\mathrm{ZrAu}_{3} \\
\mathrm{HfAu}_{3}\end{array}$ \\
\hline & & $\begin{array}{l}\text { AuGd } \\
\text { AuTb } \\
\text { AuDy } \\
\text { AuHo } \\
\text { AuEr } \\
\text { Au'Tm }\end{array}$ & $\begin{array}{l}\text { Orthorhombic } \\
\text { AuCd }\end{array}$ & $2 \mathrm{~B}$ & $\begin{array}{l}\text { AuCd } \\
\text { AuTi } \\
\text { (high T) } \\
\text { AuHf } \\
\text { (high T) }\end{array}$ \\
\hline \multirow[t]{5}{*}{$\mathrm{MoSi}_{2}$} & \multirow{5}{*}{ Rare Earths } & $\begin{array}{l}\mathrm{ScAu}_{2} \\
\mathrm{YAu}_{2} \\
\mathrm{TiAu}_{2} \\
\\
\mathrm{ZrAu}_{2} \\
\mathrm{AuZr}_{2}\end{array}$ & $\gamma \mathrm{TiCu}$ & $4 \mathrm{~A}$ & $\begin{array}{l}\gamma \text { AuTi } \\
\text { (low T) } \\
\text { AuHf } \\
\text { (low T) }\end{array}$ \\
\hline & & $\begin{array}{l}\mathrm{HfAu}_{2} \\
\mathrm{AuHf}_{2} \\
\mathrm{VAu}_{2} \dagger \\
\mathrm{MnAu}_{2}\end{array}$ & $\mathrm{ZnS}$ & $2 \mathrm{~A}$ & $\begin{array}{l}\mathrm{AuBe}_{5} \\
\mathrm{CaAu}_{5}\end{array}$ \\
\hline & & \multirow{3}{*}{$\begin{array}{l}\mathrm{AuMn}_{2} \\
\mathrm{GdAu}_{2} \\
\\
\mathrm{TbAu}_{2} \\
\mathrm{DyAu}_{2} \\
\mathrm{HoAu}_{2} \\
\mathrm{ErAu}_{2} \\
\mathrm{TmAu}_{2} \\
\mathrm{LuAu}_{2}\end{array}$} & $\mathrm{AlB}_{2}$ & $3 \mathrm{~A}$ & $\begin{array}{r}\mathrm{AuB}_{2} \\
\mathrm{ThAu}_{2} \\
\end{array}$ \\
\hline & & & $\mathrm{ZrAu}_{4}$ & $4 A$ & $\begin{array}{l}\mathrm{ZrAu}_{4} \\
\mathrm{HfAu}_{4} \\
\end{array}$ \\
\hline & & & $\beta-M n$ & $5 \mathrm{~A}$ & $\mathrm{Nb}_{11} \mathrm{Au}_{0}$ \\
\hline \multirow[t]{3}{*}{$\mathrm{Cr}_{3} \mathrm{Si}(\beta-\mathrm{W})$} & \multirow{3}{*}{$4 \mathrm{~A}$} & \multirow{3}{*}{$\begin{array}{l}\mathrm{Ti}_{3} \mathrm{Au} \\
\mathrm{Zr}_{3} \mathrm{Au} \ddagger \\
\mathrm{V}_{3} \mathrm{Au} \neq \\
\mathrm{Nb}_{3} \mathrm{Au} \neq \\
\mathrm{Ta}_{3} \mathrm{Au}\end{array}$} & $\sigma$ structure & $5 \mathrm{~A}$ & $\mathrm{Ta}_{2} \mathrm{Au}$ \\
\hline & & & NiAs & $4 \mathrm{~B}$ & $\mathrm{AuSn}$ \\
\hline & & & $\mathrm{FeSi}$ & $2 \mathrm{~A}$ & AuBe $\neq$ \\
\hline \multirow[t]{3}{*}{$\mathrm{MoNi}_{4}$} & \multirow{3}{*}{$\begin{array}{l}4 \mathrm{~A} \\
5 \mathrm{~A} \\
6 \mathrm{~A} \\
7 \mathrm{~A}\end{array}$} & \multirow{3}{*}{$\begin{array}{l}\mathrm{TiAu}_{4} \\
\mathrm{HfAu}_{5} \\
\mathrm{VAu}_{4} \\
\mathrm{CrAu}_{4}{ }^{\star} \\
\mathrm{MnAu}_{4} \star \star\end{array}$} & $\mathrm{FeS}_{2}$ & $6 \mathrm{~B}$ & $\mathrm{AuSb}_{2} \neq$ \\
\hline & & & $\mathrm{PtSn}_{4}$ & $4 \mathrm{~B}$ & $\mathrm{AuSn}_{4} \ddagger$ \\
\hline & & & $\mathrm{Na}_{3} \mathrm{As}$ & $2 \mathrm{~A}$ & $\mathrm{Mg}_{3} \mathrm{Au}$ \\
\hline \multirow[t]{2}{*}{$\mathrm{MgCu}_{2}$} & $1 \mathrm{~A}$ & $\mathrm{NaAu}_{2}$ & $\mathrm{Cu}_{3} \mathrm{Al}$ & $1 \mathrm{~A}$ & $\mathrm{Li}_{3} \mathrm{Au}$ \\
\hline & $\begin{array}{l}2 \mathrm{~A} \\
4 \mathrm{~B} \\
5 \mathrm{~B}\end{array}$ & $\begin{array}{l}(\mathrm{Au}, \mathrm{Be}) \mathrm{Be}_{2} \\
\mathrm{PbAu}_{2} \\
\mathrm{BiAu}_{2} \ddagger\end{array}$ & $\mathrm{TiNi}_{3}$ & $4 \mathrm{~B}$ & $\mathrm{Au}_{10} \mathrm{Sn}$ \\
\hline $\mathrm{AuBe}_{5}$ & $2 \mathrm{~A}$ & $\begin{array}{l}\mathrm{AuBe}_{5} \\
\mathrm{AuCa}_{5}\end{array}$ & $\mathrm{Cu}_{15} \mathrm{Si}_{4}$ & $1 \mathrm{~A}$ & $\mathrm{Li}_{15} \mathrm{~A} u_{4}$ \\
\hline \multirow[t]{2}{*}{$\mathrm{CaCu}_{5}$} & \multirow[t]{2}{*}{$\begin{array}{l}\text { IA } \\
2 \mathrm{~A}\end{array}$} & \multirow{2}{*}{$\begin{array}{l}\mathrm{KAu}_{5} \\
\mathrm{RbAu}_{5} \\
\mathrm{SrAu}_{5} \\
\mathrm{BaAu} u_{5}\end{array}$} & $\mathrm{Nb}_{3} \mathrm{Au}_{2}$ & $5 \mathrm{~A}$ & $\begin{array}{l}\mathrm{Nb}_{3} \mathrm{Au} \\
\text { "AuTa" }\end{array}$ \\
\hline & & & $\mathrm{MnP}$ & $3 \mathrm{~B}$ & $\mathrm{AuGa}$ \\
\hline \multirow[t]{2}{*}{ Fluorspar $\left(\mathrm{CaF}_{2}\right)$} & \multirow{2}{*}{$\begin{array}{l}3 \mathrm{~A} \\
3 \mathrm{~B}\end{array}$} & \multirow{2}{*}{$\begin{array}{l}\mathrm{AuAl} 1_{2} \\
\mathrm{AuGa}_{2} \\
\mathrm{AuIn}_{2}\end{array}$} & $\mathrm{CaZn}_{5}$ & $2 \mathrm{~A}$ & $\mathrm{BaAu}_{5} \ddagger$ \\
\hline & & & Diamond type & $2 \mathrm{~A}$ & $\mathrm{AuBe}_{3}$ \\
\hline
\end{tabular}




\begin{tabular}{|c|c|c|c|c|c|}
\hline \multicolumn{6}{|c|}{$\begin{array}{l}\text { Table VI } \\
\text { Intermediate Phases other than Electron Compounds-Structure Unknown }\end{array}$} \\
\hline Group of Partner & Phase & Group of Partner & Phase & Group of Partner & Phase \\
\hline $1 \mathrm{~A}$ & $\begin{array}{l}\mathrm{Li}_{4} \mathrm{Au}_{5} \\
\mathrm{LiAu} \\
\mathrm{Li}_{2} \mathrm{Au} \\
\mathrm{NaAu} \\
\mathrm{Na}_{2} \mathrm{Au} \\
\mathrm{KAu}_{2} \\
\mathrm{KAu} \\
\mathrm{K}_{2} \mathrm{Au} \\
\mathrm{BeAu}_{3} \\
\mathrm{BeAu}_{2} \\
\mathrm{Be}_{3} \mathrm{Au}_{4} \\
\mathrm{Be}_{3} \mathrm{Au} \\
\left(\mathrm{high} \mathrm{T}_{\mathrm{T}} \mathrm{yy}\right) \\
\mathrm{Mg}_{2} \mathrm{Au} \\
\mathrm{Mg}_{5} \mathrm{Au} \mathrm{u}_{2} \\
\mathrm{Mg}_{3} \mathrm{Au} \\
\mathrm{CaAu}_{3} \\
\mathrm{CaAu}_{2} \\
\mathrm{Ca}_{1 \cdot 11} \mathrm{Au} \\
\mathrm{Ca}_{2} \mathrm{Au} \\
\mathrm{Ca}_{4} \mathrm{Au} \\
\mathrm{SrAu}_{2} \\
\mathrm{Sr}_{3} \mathrm{Au} \\
\mathrm{Sr}_{9} \mathrm{Au} \\
\mathrm{BaAu}_{2} \\
\mathrm{Ba}_{2} \mathrm{Au}_{3}\end{array}$ & $\begin{array}{l}6 \mathrm{~A} \\
7 \mathrm{~A}\end{array}$ & $\begin{array}{l}\mathrm{Sc}_{2} \mathrm{Au} \\
\mathrm{AlAu}_{2} \\
\mathrm{AuAl} \\
\mathrm{LaAu}_{3} \\
\mathrm{LaAu}_{2} \\
\mathrm{La}_{2} \mathrm{Au} \\
\mathrm{C}_{2} \mathrm{Au}_{2} \\
\mathrm{TiAu}_{2} \\
\mathrm{TiAu} \\
\mathrm{ZrAu}_{4} \\
\mathrm{Zr}_{2} \mathrm{Au}_{10} \\
\mathrm{Hf}_{7} \mathrm{Au}_{10} \\
\mathrm{Th}_{3} \mathrm{Au}_{5} \\
\mathrm{NbAu}_{2} \\
\mathrm{Nb}_{3} \mathrm{Au}_{2} \\
\mathrm{Te}_{2} \mathrm{Au} \\
\mathrm{MnAu}_{4} ? \\
\mathrm{MnAu}_{3}^{\star} \\
\mathrm{X} \mathrm{Mn}-\mathrm{Au}^{\star}\left(\mathrm{richer}_{\mathrm{in}}\right. \\
\left.\mathrm{Au}_{\mathrm{than}} \mathrm{Mn}_{2} \mathrm{Au}_{5}\right) \\
\mathrm{Mn}_{2} \mathrm{Au}_{5} \\
\mathrm{MnAu}_{2} \\
\mathrm{MnAu} \\
\mathrm{Mn}_{3} \mathrm{Au} \\
\mathrm{PtAu}_{3} ?\end{array}$ & $\begin{array}{l}2 \mathrm{~B} \\
3 \mathrm{~B} \\
4 \mathrm{~B}\end{array}$ & 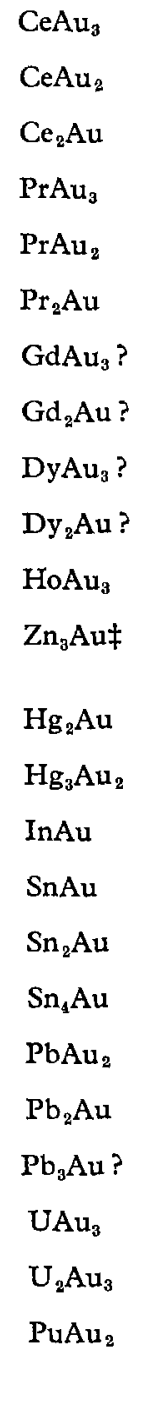 \\
\hline
\end{tabular}

Phases followed by a query are probable but not established with certainty

*Antiferromagnetic phase

$\ddagger$ Superconducting phase

\section{Conclusions}

In this review, necessarily brief and incomplete, it has not been possible to discuss the physical or mechanical properties of gold alloys, but it is hoped that the scope of our constitutional knowledge has been accurately presented. The survey indicates clearly that our knowledge of the alloying characteristics of gold is extensive, and that much of the available knowledge conforms to the general theory of alloying. The situation is such that theoretical principles may be used to assist the further development of gold alloys, and to gain an insight into the probable characteristics and constitutions of alloys with more than two components.

\section{References}

11 W. Hume-Rothery, P. W. Reynolds and G. V. Raynor, 7. Inst. Metals, 1940, 66, 191

12 W. Hume-Rothery, J. O. Betterton, Jr., and J. Reynolds, 7. Inst. Metals, 1951-52, 80, 609

13 G. V. Raynor, F. Less-Common Metals, 1974, 37, (2), 247

14 G. V. Raynor, Metal Science, 1975, 9, (9), 430

15 G. Grube, A. Schneider and U. Esch, "Festschrift aus Anlass des 100-jährigen jubiläums der Firma W.C. Heraeus G.m.b.H.", 1951, pp. 20-42

16 V. V. Sanadze, Dokl. Akad. Nauk S.S.S.R., 1961, 140, (1), 133; Proc. Acad. Sci. U.S.S.R., Chem. Sect., 1961, $140,(1), 889$ 